\title{
Prevelance of hepatitis C Viral Infections among Thalassaemic Patients in Thi -Qar Governorate
}

\author{
Ali Jerin Al-Jabrri (ali.j@utq.edu.iq) \\ Department of Pediatrics / College of Medicine \\ Thi-Qar University
}

\begin{abstract}
$\underline{\text { Abstract }}$
A prospective study was conducted on 305 patients with Thalassemia who were attending to the center of inherited blood diseases in Nassiryia city from the penod of 1 / 7 / 1997 to $30 / 9 / 2009$.
\end{abstract}

Elisa test was used to study the prove lance of hepatitis C Viral infections among Thalassaemic children .

Anti-HCV antibodies were detected in 72 ( $23.6 \%$ ) patients , 47(65\%)males and $25(35 \%)$ females. The frequency of cases was correlated with increasing age.

There was a positive correlation between frequency of blood Transfusion / year and the increased incidence of infection with HCV .

Splenectomy was done in $80(26.2 \%$ ) patients 28 ( $3 \mathrm{~S} \%$ ) of them had positive anti-HCV antibodies in their sera .

We concluded that our Thalassemic patients are exposed to HCV infection .Careful, regular screening of blood unit for HCV should be established .

\section{$\underline{\text { Introduction }}$}

Hepatitis $\mathrm{C}$ is an infectious disease affecting the liver, caused by the hepatitis $\mathrm{C}$ virus (HCV) (1) .

The infection is often asymptomatic, but once established, chronic infection can progress to scarring of the liver (fibrosis), and advanced scarring (cirrhosis) which is generally apparent after many years . in some cases, those with cirrhosis will go on to develop liver failure or other complications of cirrhosis ، including liver cancer (1) .

The hepatitis $\mathrm{C}$ virus (HCV) is spread by blood - to - blood contact . The virus persists in the liver in about $85 \%$ of those infected (2).

Persistent infection can be treated with medications ' peginterferon and ribavirin being the standard - of - care therapy . $51 \%$ are cured overall $(3,4,7)$. Those who develop cirrhosis or liver cancer may require a liver transplant and the virus universally recurs after transplantation (6) . 
An estimated 270-300 million people worldwide are infected with hepatitis C . (5) . Hepatitis $C$ is a strictly human disease . No vaccine against hepatitis $C$ is available .

The existence of hepatitis C (originally non - A non - B ) hepatitis ) was postulated in the 1970 and proved conclusively in 1989 . It is one of five known hepatitis viruses : $\mathrm{A}, \mathrm{B}, \mathrm{C}, \mathrm{D}$ and $\mathrm{E}$. This study was carried out to establish the prevalence of hepatitis $\mathrm{C}$ virus infection among Thalassaemic children in Thi-Qar city .

\section{Patients and methods}

Three hundred live thalassemic children ( 165 (54\%) males and 140 (46\%) females ).

Who were attending the center of inherited blood diseases in Nassiriyia from the period of 1.7.1997 to 30.9.2009, were included in the study .

A thorough physical examination of each individual was carried out and history regarding age , date of diagnosis, sex ، vaccination status ، history of splenectomy and frequency of blood transfusion / year were recorded .

Blood samples $(5-10 \mathrm{ml})$ were collected and sent to the central health laboratory in the governorate to detection of Anti-HCV antibodies by using ELISA test murex anti-HCV (version 4.0) .

\section{$\underline{\text { Results }}$}

Out of 305 Thalassaemic children studied, males were 165 (54\%), females were $140(46 \%)$ The age range of the Thalasseamics was between ( 4 mo-38 years ).

Anti-HCV antibodies were positive in $72(23.6 \%)$ patients, male cases were $47(65 \%)$, females were $25(35 \%)$ as shown in Table (1).

Table (1) Distribution of Anti HOV a.b according to demographic characteristics among Thalassemic patients In ThI-Qar.

\begin{tabular}{|c|c|c|c|c|c|c|c|c|}
\hline \multirow{2}{*}{$\begin{array}{c}\text { Age } \\
\text { (years) }\end{array}$} & \multicolumn{4}{|c|}{ Males } & \multicolumn{4}{|c|}{ Females } \\
\hline & No. & $\%$ & $\begin{array}{l}+\mathrm{Ve} \\
\text { Anti - } \\
\mathrm{HCV}\end{array}$ & $\%$ & No. & $\%$ & $\begin{array}{l}+\mathrm{Ve} \\
\text { Anti - } \\
\mathrm{HCV}\end{array}$ & $\%$ \\
\hline$<5$ & 25 & 15.1 & 6 & 24 & 19 & 13.5 & 3 & 15.70 \\
\hline $5-10$ & 34 & 20.0 & 8 & 23.5 & 24 & 17 & 5 & 20.8 \\
\hline $11-15$ & 44 & 26.6 & 11 & 25 & 40 & 28.5 & 7 & 17.5 \\
\hline $16+$ & 62 & 37.5 & 22 & 35.48 & 57 & 40.7 & 10 & 17.5 \\
\hline Total & 165 & 100 & 47 & 22.4 & 140 & 100 & 25 & 17.8 \\
\hline
\end{tabular}


There was a significant difference in the prevalence of anti-HCV antibodies among our patients according to age as there was an increasing rate of infection in older age groups . Anti-HCV prevalence seemed to be increased with increasing frequency of blood transfusion .

Anti-HCV prevalence was 3.9\% (1/26) , 21\% (20/95) 28\% (51/184) among thalassaemics. who have been transfused $1-5 \leq 6-10$ and $>10$ times / year respectively. Table (2).

Table (1) Distribution of Anti HCV a.b according to number of blood unites received among Thalassaemic patients

\begin{tabular}{|c|c|c|c|}
\hline \multirow{2}{*}{$\begin{array}{c}\text { NO . of transfusion } \\
\text { unites / year }\end{array}$} & \multicolumn{2}{|c|}{ Anti-HCV a.b } & \multirow{2}{*}{ Total } \\
\cline { 2 - 4 } & Positive & Negative & \\
\hline $\mathbf{1 - 5}$ unites / year & $1(3.9 \%)$ & $25(96.2)$ & $26(8.5 \%)$ \\
\hline $\mathbf{6}-\mathbf{1 0}$ unites / year & $20(21)$ & $75(79 \%)$ & $95(31.15)$ \\
\hline$>\mathbf{1 0}$ unites / year & $51(28 \%)$ & $133(72.3)$ & $184(60.35 \%)$ \\
\hline Total & $72(23.6 \%)$ & $233(76.4)$ & $305(100 \%)$ \\
\hline
\end{tabular}

$\mathrm{X}^{2} \quad 15.75 \quad \mathrm{P}<0.01$

History of splenectomy was positive in 80 patients (26.2\%) 28

$(35 \%)$ of them got HCV Antibodies in their sera as shown in Table ( $r)$.

Table (3) Distribution of Anti HCV a.b among Splenectomized and non Splenectomized Patients in studied population

\begin{tabular}{|c|c|c|c|}
\hline \multirow{2}{*}{ Splenectonized } & \multicolumn{2}{|c|}{ Anti-HCV a.b } & \multirow{2}{*}{ Total } \\
\cline { 2 - 4 } & Positive & Negative & \\
\hline Non & $28(35 \%)$ & $52(65.2)$ & $80(26.23 \%)$ \\
\hline Total & $44(19.5)$ & $181(80.5 \%)$ & $225(73.8 \%)$ \\
\hline
\end{tabular}

$\mathrm{X}^{2} \quad 10.7 \quad \mathrm{P}<0.05$

The study showed that $(23.6 \%)$ ofthalassemic children in Thi-Qar governorate were positive for HCV antibodies. This rate is similar to that reported in Sulaimanyah center and Ibn Al-Bladey hospital center, but higher than figures reported in the other governorates as shown in Table (4) 
Table (4) Prevalence of Anti HCV among thalassemics in Iraq Governorates

\begin{tabular}{|c|c|c|c|c|}
\hline Governorate & $\begin{array}{c}\text { Total No . of } \\
\text { patients }\end{array}$ & $\begin{array}{c}\text { Anti - HGV } \\
\text { virus }\end{array}$ & $\%$ & Reference \\
\hline Diayala & 287 & 51 & 17.7 & Dr. Abdul RAZZAQ \\
\hline Babel & 599 & 65 & 10.9 & Dr. Ahmed Shemran \\
\hline Al-Emmara & 285 & 31 & 10.9 & Dr. Haider \\
\hline $\begin{array}{c}\text { Ibn Al-balady } \\
\text { hospital }\end{array}$ & 1750 & 380 & 21.7 & Dr. Zainab \\
\hline Diwanyah & 306 & 12 & 3.9 & Dr. Jawad Abbas \\
\hline Sulaimanyah & 600 & 137 & 22.8 & \begin{tabular}{c} 
Dr. luqman Khalid \\
\hline Thi - Qar
\end{tabular} \\
\hline & 305 & 72 & 23.6 & $\begin{array}{c}\text { Present study } \\
\text { Dr. Ali Jerin }\end{array}$ \\
\hline
\end{tabular}

\section{$\underline{\text { Discussion }}$}

The increased rate of $\mathrm{HCV}$ infectious with increasing age was in agreement with other studies $(8,9)$.

The higher anti-HCV prevalence in older age groups may reflect the effect of multiple exposure to $\mathrm{HCV}$ during their life.

Previous studies revealed that when the number of transfusion exceeds 10 times there would be a greater risk of infection with HCV 10,11.12).

The higher frequency of positive HCV antibodies among splenectomized children indicate that splenectomy may alter immunity a giant HCV infection .

Another explanation is that splenectomized children are older children requiring frequent blood transfusions and hypersplenism. From this study we conclude that high elevated rate of $\mathrm{HCV}$ infection among Thalassemic children in Thi-Qar governorate and more in splenectomized patients .

There was a positive correlation between frequency of blood transfusion and risk of hepatitis $\mathrm{C}$ virus infection .

\section{$\underline{\text { Recommendation }}$}

1. Careful screening and selection of blood donors for $\mathrm{HCV}(15)$

2. Using more advance instrument to detected the HCV like PCR .

3. The splenectomy should be done if seriously needed . 
4. Provision of anti HCV therapies ( interferon or interferon + ribavirin ) to prevent progression to further complications (13).

5. All patients with HCV should be immunized with hepatitis B vaccin to minimize further hepatic injury (14).

6. Frequent monitoring and follow-up for possible development of chronic liver disease .

\section{$\underline{\text { Reference }}$}

1- Ryan KJ. Ray CG ( editors ) ( 2004 ). Sherris Medical Microbiology ( 4 th ed. ). McGraw Hill . pp. 551-2. ISBN 0838585299.

2- Caruntu FA, Benea L ( September 2006 ). " Acute hepatitis C virus infection : Diagnosis , pathogenesis , treatment ( http ://www.jgld.ro/32006/32006 .html ) " . Journal of Gastrointestinal and Liver Diseases : JGLD 15 ( 3 ) : 249-56 PMID 17013450 ( http:// www.ncbi.nlm.nih.gov/pubmed / ( 17013450 ) http:-//www. jgld.ro/32006/32006 7.html.Retrieved $2009-08-01$.

3- Kamal SM ( May 2008 ) . Acute hepatitis C:a systematic review . The American Jornal of Gastroenterology 103 (5) : 1283-97, quiz 1298 . doi:10.1111/j.15720241.2008.01825.x ( http://dx.doi.org / 10.1111/j.1572 0241.2008.01825.x). PMID 18477352 (http://www.ncbi.nlm.nih.1ov/oubmed/18477352) .

4- Villano SA, Vlahov D, Nelson KE,Cohn S,Thomas DL (1999 ) . " Persistence of viremia and the importance of long -term follow -up alter acute hepatitis C infection " . $\begin{array}{lllllll}\text { Hepatology } & 29 & \text { (3) } \quad \text { : } & 908-14 \quad \text { doi:10.1002/hep.51029031 }\end{array}$ )http://dx.doi.org/10.1002/heo.510290311) . PMID _ 10051497 (http//www.ncbi.nlm.nih.gov/pubmed/10051497

5- Cox AL, Netski DM, Mosbruger T, et a1. ( 2005 ). " Prospective infection " Clin. Infect . Dis. 40 ( 7) : community - acquired - acute phase hepatitis c virus (http //www.ncbi.nlm.nih.gov/pubmed/15824985 ) 951-8.doi:10.1086/428578 http://dx.doi.org/10.1086/428578 ). PMID 15824985)

6 - NIH Consensus Development Conference on Man6 Hepatitis C : 2002 (http://consensus.nih.gov/2002/2002HepatitisC20021 16main.ht m ) “ (http://consensus.nih.gov/2002/2002HepatitisC20021 16main.ht m.Retrieved2008-02-22 .

7- Jaeckel E, Comberg M, Wedemeyer H, Santantonio T, Mayer J, Zankel M, Pastore G, Dietrich M, Trautwein C, Manns MP ) (November 2001 ). " Treatment of acute hepatitis $\mathrm{C}$ with interferon alfa- $2 \mathrm{~b} "$. 
8- Sherlock S. Dooley J.Viral hepatitis is of the liver and biliary system . Black well scientific publication, 17th edition, 2007 , 265-302 .

9- Dienstog J ,Isselbachesr K. Acute viral hepatitis, in .Harrison's principle of internal medicine, 13th Ed. 2004 , 1459-1462.

10- Fishman LN, Janas MM, Lavine JE, Update on viral hepatitis in children . Pediatr Clinics North Am 2006, 43:57.

11- Laim , Lisci V, Argidu F,et al Prospective study of post transmsion hepatitis in polytransfused thalassaemic Children . International Symposium on viral hepatitis and liver disease . Tokyo (Abstract) .2003, 500-573.

12-Jawet 2E, Melnick L. Hepatitis viruses, In : Medical microbiology, let edition2008.

13- Mc Hutchison JG, Gordon SC, ShiffER, et al. Interferon alfa-2b alone or in combination with ribaviri as initial treatment for chronic hepatitis $\mathrm{C}-\mathrm{N}$.Eng $\mathrm{J}$ Med 2005. 339: 1485 .

14- Center for Disease Control and prevention: 15- Recommendations for prevention and control of hepatitis $\mathrm{C}$ virus ( $\mathrm{HCV}$ ) infection and HCV-related chronic disease . MMWR 47(RR-19): 1,1998 .

16- Al-Watify AS, Hassan MK. Prevalence of hepatitis $C$ virus infection among multitransfused thalassemic children in Basrah - Iraq. Qatar Medical Journal 2000, 9(2):58-61. 


\title{
دراسة مستوى انتشار التهاب الكبد الفايروسي نوع (ج) عند مرضى الثُلاسيميا في محافظة ذي قار
}

\author{
الاكتور علي جرن الجابري \\ قسم الأطفال/ كلية الطب / جامعة ذي قار
}

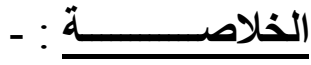

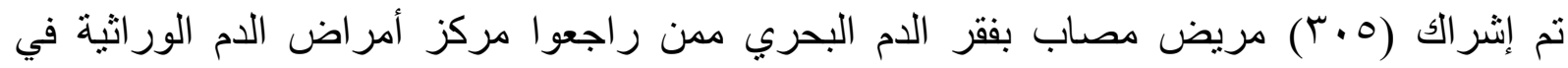

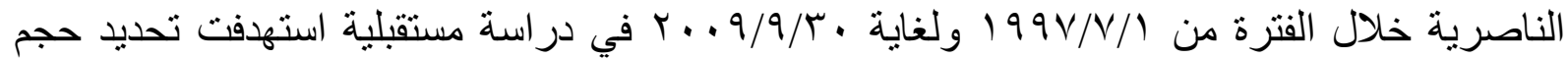
مثكلة الإصابة بالتهاب الكبد الفيروسي نوع (ج) عند مرضى الثثلاسيميا بو اسطة فحص (تلفية (Elisa) .

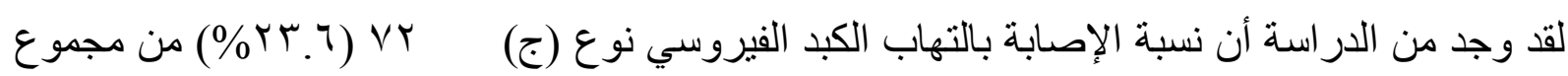

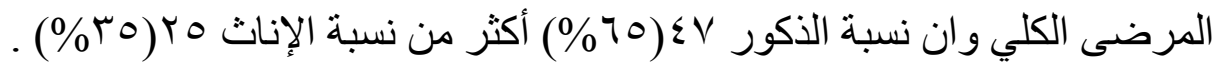
لقد وجد في الدر اسة أن أغلب الإصابات تزداد مع تقدم العمر. كذللك وجد هناك زيادة في نسبة الإصابة في التهاب الكبد الفيروسي نوع (ج) مع زيادة عدد مرات إعطاء

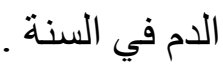

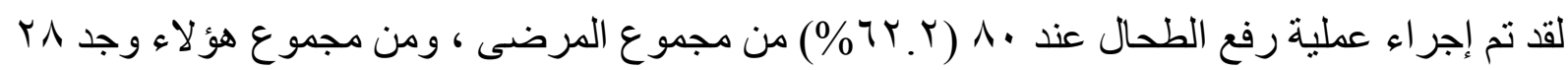

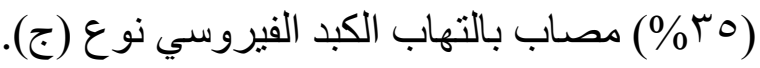

نستنتج من هذه الدراسة أن مرضى الثلاسيميا اكثر عرضة للإصابة بالتهاب الكبد الفيروسي نوع (ج)

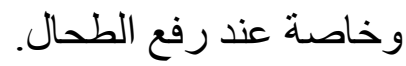
لقد ركزت الدر اسة بالتأكيد على إجر اء الفحص الاستكثافي للفايروس عند المنبر عين بالدم بصورة دورية ومنتظمة. 